\title{
Aboriginal children suffer while governments ignore Jordan's Principle
}

$\mathrm{U}$ nder Jordan's Principle, ${ }^{1}$ which was unanimously approved by Canada's Parliament in December $2007^{2}$ and subsequently adopted by most provinces and territories, no Status Indian or Inuit child should be denied services due to a jurisdictional funding dispute between two government parties (provincial/territorial or federal) or between two departments or ministries of the same government. The needs of the child take precedence; jurisdictional disputes can be resolved later.

It seems, however, that governments are merely paying lip service to a politically correct idea. Neither the Government of Canada nor any of the provinces or territories have strong implementation plans. In a recent report on public policy, ${ }^{3}$ all of the provincial and territorial governments, except for that of Nova Scotia, received fair or poor grades in implementing Jordan's Principle. Nova Scotia scored a good rating because it has a tripartite agreement between the federal government, the provincial government, and Mi'kmaq Family and Children's Services of Nova Scotia that "provides a mechanism for dispute-resolution to address children's needs, including special medical requirements." 3

But even this has not helped Jeremy Meawasige, a teenaged member of the Pictou Landing First Nations, who has severe disabilities including hydrocephalus, cerebral palsy, autism, meager speech ability and major mobility limitations. ${ }^{4} \mathrm{He}$ has required total personal care since birth care that his mother, Maurina Beadle, provided with love and attention, but without government support, until she had a stroke in 2010. The Band Council stepped in to provide inhome support for Jeremy and his mother, and asked the federal government for additional funds to ensure the Beadles received the same level of care as other Nova Scotians.

The Government of Canada refused, saying that the Beadles, who live on-reserve, are entitled to only $\$ 2200$ of the $\$ 8200$ monthly it now costs for Jeremy's home care, even though a Nova Scotia court has ruled that arbitrarily capping benefits is illegal and that assistance should match need. ${ }^{4}$ To add insult to injury, the Government of Canada calls the court's decision "not relevant."

The Band Council is struggling to pay the Beadles' bills, which consume a large part of the relevant home care budget for the whole band. ${ }^{4}$ Without support, Jeremy may be separated from his mother and moved into a care home offreserve, a terrible nonsolution for a loving mother and her child with severe disabilities. Not surprisingly, both the band and Ms. Beadle are taking the federal government to court. However, that will take both money and time. Even one year away from his mother will feel like forever to a child with major disabilities and meager ability to communicate.

The position of the federal government is simply wrong, constituting outright discrimination against Jeremy solely because he lives on-reserve, and totally undermines the precepts of Jordan's Principle. Jeremy's case is one of equity of access to health care, a right under the Canadian Charter of Rights and Freedoms. As we noted on this page in 2007,

The point isn't what portion of the cost the federal, territorial and provincial governments each pay but, rather, that the wrangling stop so that the right care, at the right place, at the right times can be provided for people on First Nations' reserves.

Unfortunately, there are many Jeremys. Harriet SumnerPruden of Manitoba has filed a human rights complaint over the denial of equitable care on-reserve for her son Dewey. ${ }^{6}$ Cindy Blackstock, executive director of the First Nations Child and Family Caring Society of Canada, estimates that at least 50 such jurisdictional disputes occur in Canada each year (personal communication, 2012).

Fundamental change is needed. The Government of Canada has a poor track record in health administration. Has the time come to rethink how and who administers health care on Aboriginal reserves? Too many vulnerable children, voiceless in decision-making, remain in bureaucratic limbo, victims of government foot dragging and ongoing bitter arguments. These children cannot wait, and neither can we.

\section{Noni E. MacDonald MD MSc}

Section Editor, Population and Public Health, CMAJ

\section{References}

1. National Collaborating Centre for Aboriginal Health. Fact sheet: Jordan's Principle. Prince George (BC): The Centre. Available: www.nccah-ccnsa.ca/docs /JordanPrinciple.pdf (accessed 2012 Jan. 25).

2. Private members' business M-296. Parliament of Canada Journals, 39th Parl, 2nd Sess, No. 36 (Dec. 12, 2007). Available: www.parl.gc.ca/HousePublications/Publication .asp ? pub $=$ Journals $\&$ doc $=36 \&$ Language $=E \&$ Mode $=1 \&$ Parl $=39 \& S e s=2($ accessed 2012 Jan. 25).

3. Canadian Paediatric Society. Are we doing enough? A status report on Canadian public policy and child and youth health. 2012 Edition. Ottawa (ON): The Society; 2012. Available: www.cps.ca/English/Advocacy/StatusReport2012.pdf (accessed 2012 Jan. 25).

4. Applicants' memorandum of fact and law between Pictou Landing Band Council and Maurina Beadle and Attorney General of Canada (23 November 2011) Court File Number: T-1045-11. Available: www.fncfcs.com/sites/default/files/jordans -principle/docs/Applicants-Factum-T-1045-11.pdf (accessed 2012 Jan. 25).

5. MacDonald N, Attaran A. Jordan's Principle, governments' paralysis. CMAJ 2007; $177: 321$.

6. Sanders C. Gaps remain for First Nations special-needs kids: Jordan's Principle still an unfulfilled promise. Winnipeg Free Press. 2011 Feb. 3. Available: www.winnipeg freepress.com/local/gaps-remain-for-first-nations-special-needs-kids-115170099.html (accessed 2012 Feb. 6).

Competing interests: See www.cmaj.ca/site/misc/cmaj_staff.xhtml

Affiliation: See www.cmaj.ca/site/misc/cmaj_staff.xhtml

Correspondence to: $C M A J$ editor, pubs@cmaj.ca

CMAJ 2012. DOI:10.1503/cmaj.120193 